\title{
Investigating the challenges of physicians' participation in accreditation programs from the perspective of physicians in public hospitals
}

Hosein Ebrahimipour

Social Determinants of Health Research Center, Mashhad University of Medical Sciences, Mashhad, Iran.

Department of Health Management and Economics, School of Health, Mashhad University of Medical Sciences

Elahe Hooshmand

Social Determinants of Health Research Center, Mashhad University of Medical Sciences, Mashhad, Iran.

Department of Health Management and Economics, School of Health, Mashhad University of Medical Sciences

Mehdi Varmaghani

Social Determinants of Health Research Center, Mashhad University of Medical Sciences, Mashhad, Iran.

Department of Health Management and Economics, School of Health, Mashhad University of Medical Sciences

Javad Javan-Noughabi

Social Determinants of Health Research Center, Mashhad University of Medical Sciences, Mashhad, Iran.

Department of Health Management and Economics, School of Health, Mashhad University of Medical Sciences

Seyyed Morteza Mojtabaeian * Department of Health Management and Economics, School of Health, Student Research Committee, Mashhad University of Medical Sciences. (Corresponding Author) :

mojtabaeianm971@mums.ac.ir

Received: 2021/09/10

Accepted: 2021/11/6

Doi: $10.52547 /$ ijhehp.9.4.383

\section{ABSTRACT}

Background and Objective: Due to the increasing pressure on hospitals to increase the quality of services, the need for physicians to participate in quality improvement programs, especially hospital accreditation, has become more important. Therefore, the present study was conducted to determine the challenges of physicians' participation in accreditation programs in Mashhad city, eastern Iran Materials and Methods: This descriptive-analytical cross-sectional study was conducted in 1399 using a questionnaire in 12 hospitals in the east of the country that performed accreditation. This questionnaire examined the challenges of physicians' participation in accreditation programs in hospitals. Finally, 445 physicians participated in the study and the participation rate was reported to be about $24 \%$. Data analysis was performed at two levels of descriptive and inferential statistics using STATA V.14.

Results: The findings of the present study showed that among the challenges of physicians' participation in accreditation programs in hospitals, the strongest challenge from the perspective of physicians is related to the dimensions of effective communication $(4.05 \pm 0.74)$ and the empowering physicians about accreditation and quality improvement $(3.89 \pm 0.59)$. Also, the weakest of them was related to the dimension of ambiguity in role $(0.96 \pm 2.86)$. Among the studied challenges, only the score of patient demand dimension showed a statistically significant difference between different medical specialties $(p<0.05)$.

Conclusion: The implementation of this program can be improved through Culture building, proper accreditation training and quality improvement activities in the medical community helped to implements.

Keywords: Hospital, accreditation, quality improvement, Physicians Paper Type: Research Article.

Citation (Vancouver): Ebrahimipour H, Hooshmand E, Varmaghani M, JavanNoughabi J, Mojtabaeian M. Investigating the challenges of physicians' participation in accreditation programs from the perspective of physicians in public hospitals . Iran J Health Educ Health Promot. Winter 2022;9(4): 383-397.

- Citation (APA): Ebrahimipour H., Hooshmand E., Varmaghani M., Javan-Noughabi J., Mojtabaeian M. (Winter 2022). Investigating the challenges of physicians' participation in accreditation programs from the perspective of physicians in public hospitals . Iranian Journal of Health Education \& Health Promotion., 9(4), 383-397. 


\section{بررسى جالشهاى مشاركت يزشكان در برنامهاه اعتباربخشى از ديدكاه يزشكان شاغل

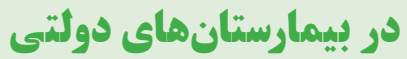

\section{جكيده}

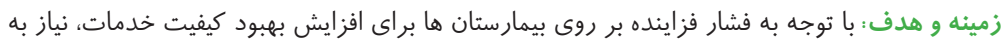

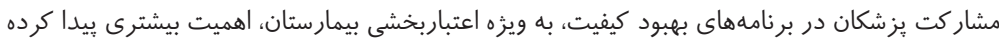

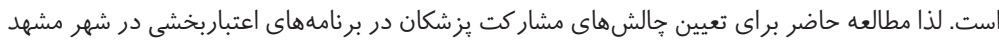
در شرق ايران انجام شده است.

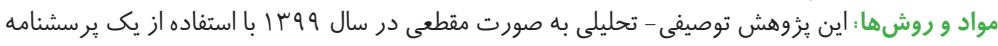

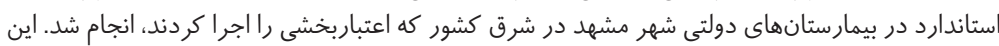

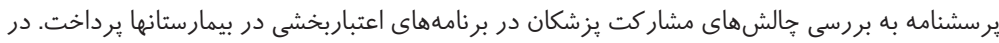

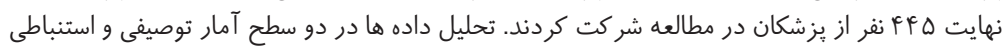

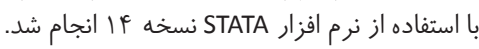

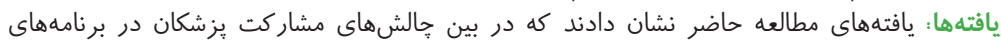

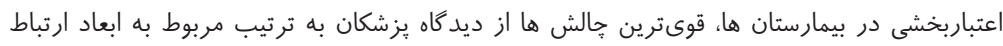

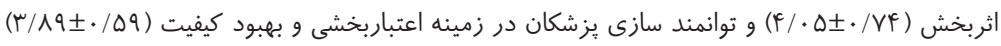

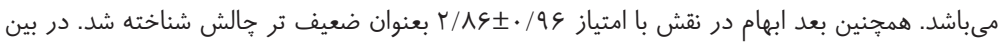

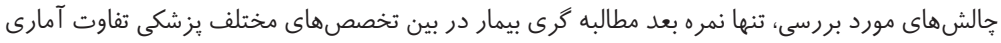

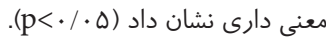

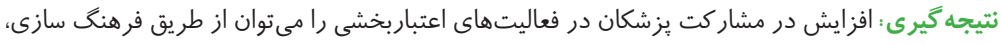

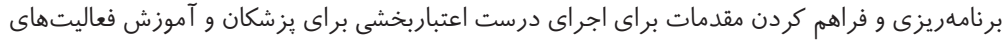

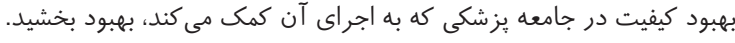

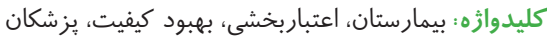

نوع مقاله : مطالعه يزوهشى.

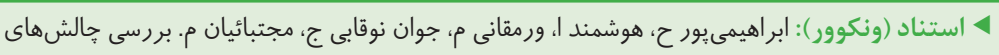

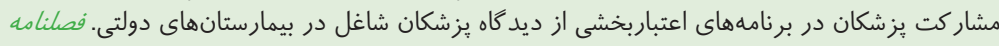

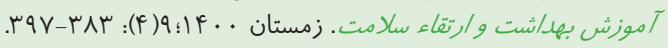

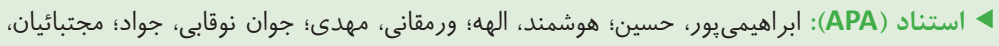

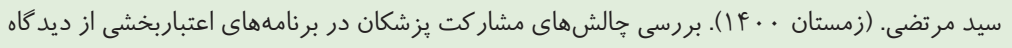

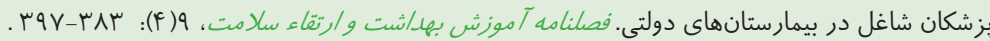

\section{(2)}

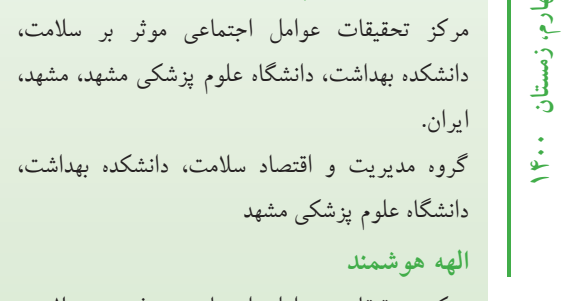

مركز تحقيقات عوامل اجتماعى موثر بر سلامت، دانشكده بهداشت، دانشكاء علوم يزشكى مشهد، مشهد، كروه مديريت و اقتصاد سلامت، دانشكده بهداشت، دانشكا، علوم يزشكى مشهد

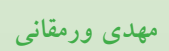
مركز تحقيقات عوامل اجتماعى موثر بر سلامت، مانى

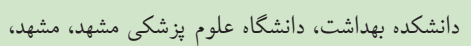
كروه مديريت و اقتصاد سلامت، دانشكده بهداشت، دانشكاه علوم يز شكى مشهد

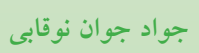

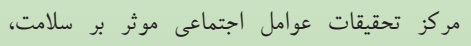

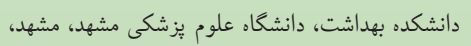
كروه مديريت و اقتصاد سلامت، دانشكده بهداشت، دانشكاء علوم يزشكى مشهد سيد مرتضى مجتبائيان

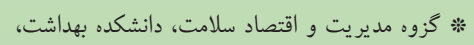

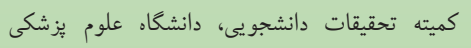

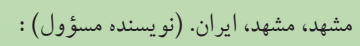
mojtabaeianm971@mums.ac.ir

تاريخ د ريافت: 9 | | | تاريخ يذيرش: تاريخ: 
آموزشى در مهارت هاى مرتبط با مديريت خدمات بهداشتى و يا اعتباربخشى و بهبود كيفيت مؤثر وجود ندارد (Q-V). در مطالعه

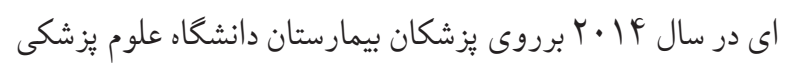
اصفهان عنوان شد كه بسيارى از مشكلات عدم مشاركت يزشكان در برنامههاى حاكميت بالينى را مى توان با آموزش مناسب آنها، ايجاد انكيزه مناسب و تسهيل مشاركت آتى آنها برطرف نمود. البته هر كدام از اين راهكارها نيازمند در نظر كرفتن شرايط خاص منطقه و بيمارستان مورد نظر دارد (N). در مطالعه اي در سال ها • ب در ميان كار كنان بهبود كيفيت بيمارستانهاى انگلستان، مسئوليت حرفه اى يزشكان براى انجام هر دو نقش مستقيم مراقبت بالينى و كمك به بهبود كيفيت خدمات به وضوح شرح داده شده است. جندين طرح وجود دارد كه يزشكان جوان رادر تعامل و آموزش در بهبود كيفيت هدف قرار داده اند و موفق بوده اند (9). مطالعه ى ديخرى كه در بين متخصصين حوزه بهبود كيفيت دانمارك انجام شد، جالش ها، نقش و نكرانى هاى يزشكان در مورد جُخونگى اجراى حاكميت بالينى را توضيح داده است. در اين مطالعه بيان شد كه مقاومت يزشكان در برابر فرايندهاى بهبود كيفيت، در همه كشورها و سيستم هاى بهداشت عمومى رايج است ( • (1). در حالى كه بسيارى از سازمان ها معتقدند كه مشاركت يزشك در كيفيت و ايمنى مهم است، تعر يف، اندازه كيرى و بهبود

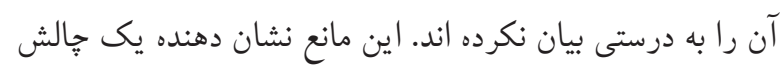
مهم براى رهبران نظام سلامت است كه در تلاش براى دستيابى به

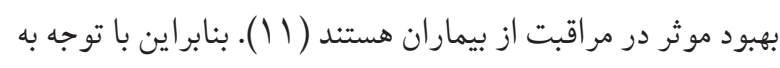
نقش حائز اهميت فر ايندهاى اعتباربخشى در بهبود كيفيت خدمات بهداشتى درمانى و نقش قابل توجه يزشكان در اين فرايند و نيز با توجه به اينكه به نظر مىرسد تاكنون مطالعه اى در ايران به جالشهاى مشار كت يزشكان در برنامههاى اعتباربخشى نيرداخته است، مطالعه حاضر با هدف بررسى جالش هاى مشار كت يزشكان در برنامه هاى اعتباربخشى در بيمارستان هاى دولتى شهر مشهد در

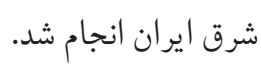

همهى سازمان ها به منظـور رقابـت در محـيط و نيـز بــراى بقـاى ماى خـود بـه دنبـال كيفيـت ارائـه خـدمات هـستند. سازمانهاى بهداشتى و درمانى نيز از اين امر مسستثنى نيسستند. در بخش خدمات بهداشتى موضـوع كيفيـت جايخـاه ويـزه اى دارد، زيرا وظيفه و رسالت خطير حفظ سـلامت و مراقبـت از حيات جامعه بر عهده اين بخش است. از سوى ديخر، ماهيت ويثه خدمات يزشكى و نداشتن تخصص ارباب رجـوع در ارزيـابى اين خدمات باعث مـيشـود حتـى يـكى اشـتباه در درمـان بيماران، ييامدهاى بسيار جـدى و هزينـهى كزافسى را بـه آنهـا تحميل كند (1). يكى از روشهاى بهبود كيفيت خدمات بهداشتى و درمانى، اعتباربخشى است. در واقع اعتباربخشى به معناى فرآيند كنترل و ارزشيابى ييشبرد برنامه يك موسسه يا اثربخشى بيشرفت بر اساس معيارهاى از قبل تعيين شده و استاندارد مى باشد و جهت استقرار اين استانداردها در بيمارستان ها نياز به تمهيدات و صرف نيروى زيادى مى باشد(ب). مشاركت يزشكان و رهبرى بالينى در استراتثى هاى سازمانى براى بهبود كيفيت، يك ييش شرط ضرورى براى ارائه مراقبت هاى ايمن و با كيفيت بالا است. زيرا يزشكان نقش اصلى را در مديريت بالينى بيماران در درون سيستم مراقبت بهداشتى ايفا مى كنند (r).

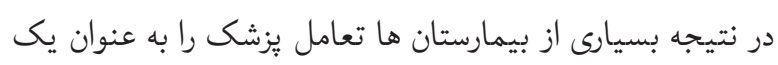
اولويت استراتثيك برتر يذيرفته اند. يزشكان بايد در فعاليت هاى بهبود كيفيت و اعتباربخشى شركت كنند تا سيستمهاى ايمن ترى داشته باشيم و شواهد بِيشين نشان مى دهد كه ايمنى و بهبود كيفيت زمانى كه يزشكان مشغول و متعهد به سيستم هستند، بالاتر است (f). يزشكانى كه در فعاليت هاى كيفيت و ايمنى فعاليت مى كنند، به عنوان يك رهبر، قادر به تمركز بر نتايج بيمار و الهام بخشيدن به همكاران براى بهبود مراقبت بيماران هستند (f).

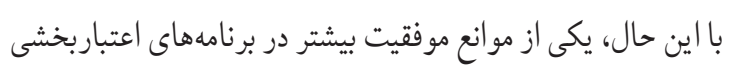
و بهبود كيفيت ممكن است عدم استفاده از مهارت هاى يزشك باشد. برنامه هاى آموزش يزشكان تقر يبا به طور كامل بر روى دانش و مهارت بر ایى مدير يت مشكالت بالينى تمر كز مى كنند و تقر يبا هيج 


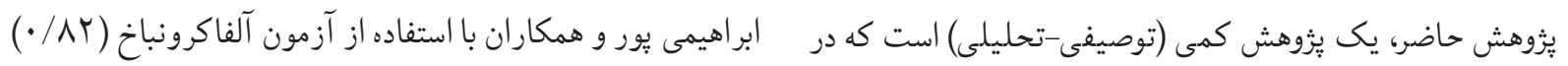

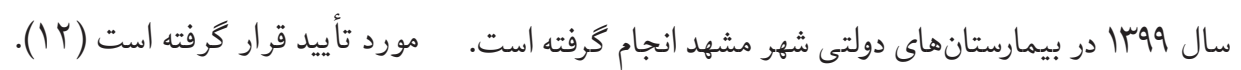

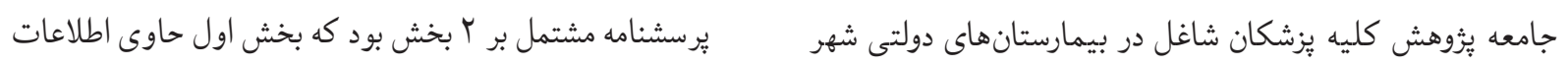

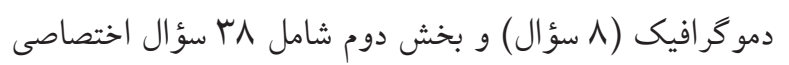
در با بعد بود.

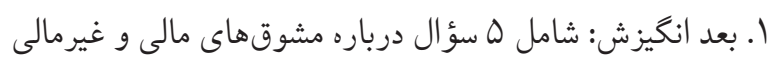

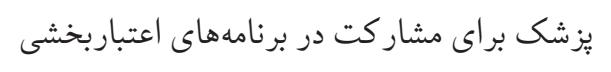

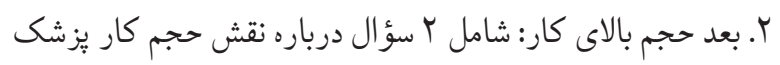

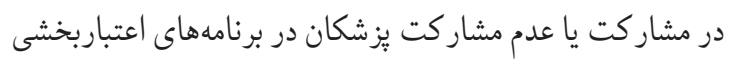

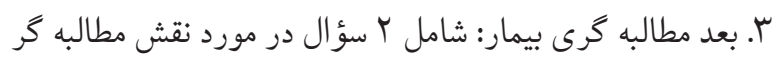

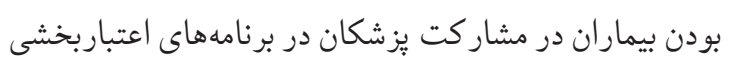
F

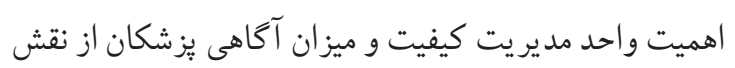
اين واحد ه. بعد ابهام در نقش: شامل r سؤال درباره نقش جندشغله بودن

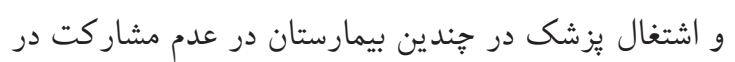

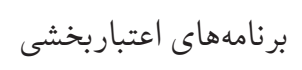

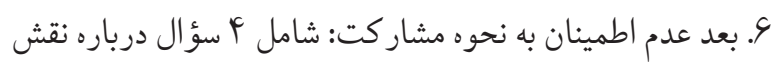

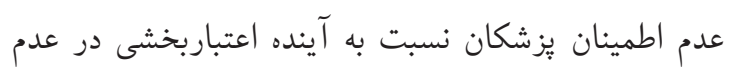

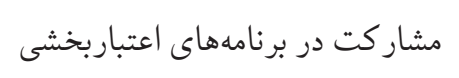

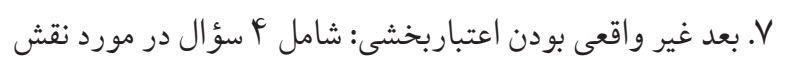

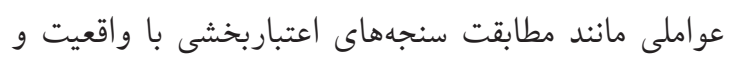

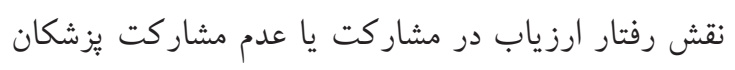

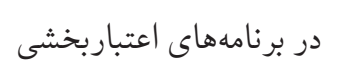

^. بعد ماهيت اعتباربخشى: شامل ^ سؤال در مورد نقش ماهيت

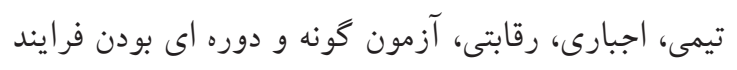

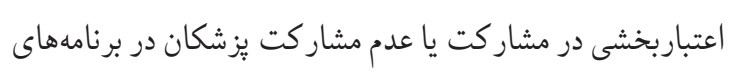

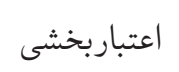

9. بعد اطمينان متقابل و نظام ارزيابى: شامل r سؤال درمورد

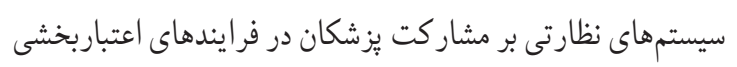

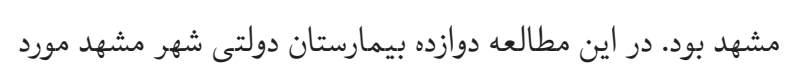
مطالعه قرار كرفته اند كه در جدول شماره النشان داده شده است.

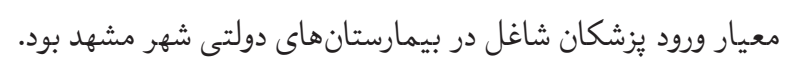

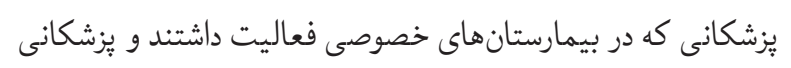

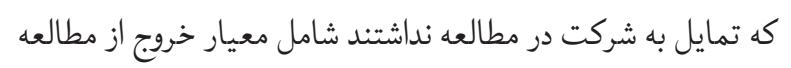

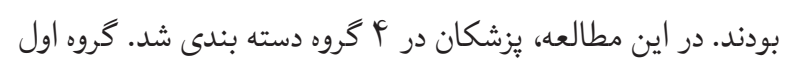

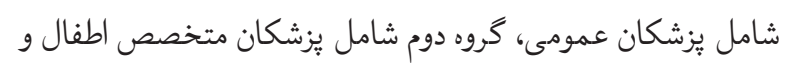

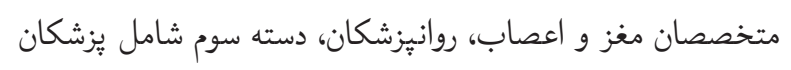

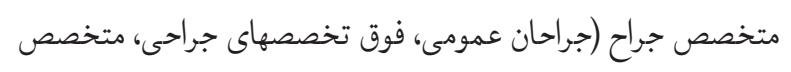

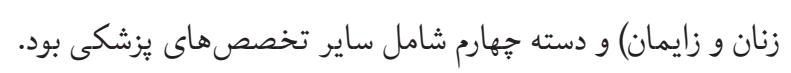

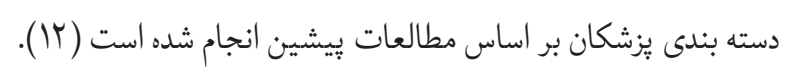

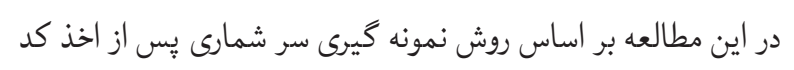
اخلاق و كسب مجوزهاى لازم بر اساس دسته بندى يزشكان ايميل ندان

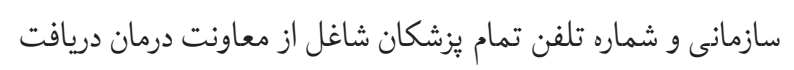

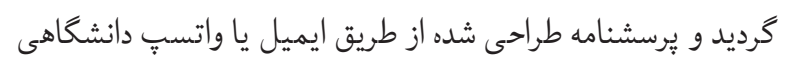

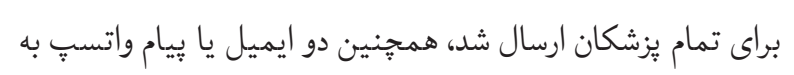

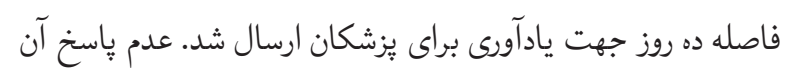

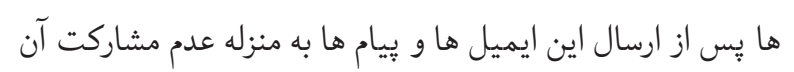
ها در مطالعه بود. در نهايت هو

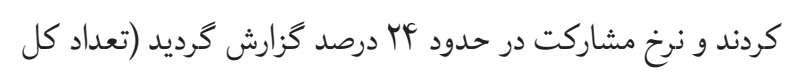

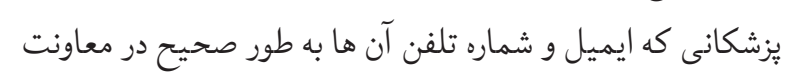

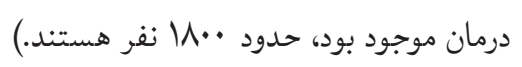

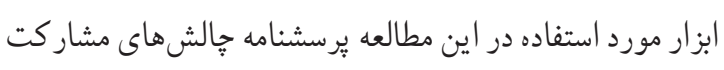
يزشكان در اعتباربخشى مى باشد كه روايى صورى و محتو ايى آن

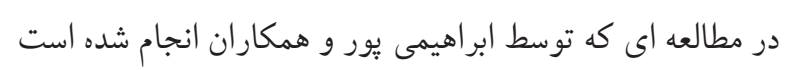
توسط اساتيد و صاحب نظران مديريت و اقتصاد سلامت و يز شكان

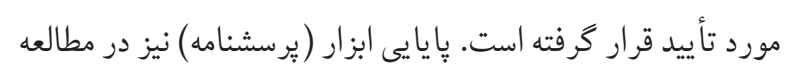


هيئت علمى دانشكاه و DF\% غير هيئت علمى بودند، بيشترين افراد

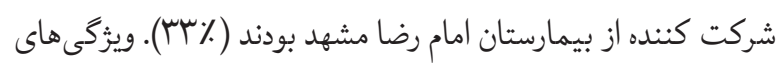
جمعيت شناختى افراد شركت كننده در مطالعه در جدول ا نشان داده شده است.

جدول ا : فراوانى ويثخىهاى جمعيت شناختى يزشكان شركت كننده در مطالعه جمعيت شناء

\begin{tabular}{|c|c|c|}
\hline تعداد (درصد) & & مشخصات \\
\hline$\left(\boldsymbol{r}^{\prime} \wedge\right) \backslash \varsigma q$ & زير • F سال & \\
\hline$(\Delta q) r \& \mu$ & • F تا .ع سال & سن \\
\hline س & بالاى •s سال & \\
\hline
\end{tabular}

\begin{tabular}{|c|c|c|}
\hline ו ו & مرد & \\
\hline$(\mathcal{F} \wedge) \boldsymbol{Y} \mid \mathcal{F}$ & زن & ידשת \\
\hline
\end{tabular}

\begin{tabular}{|c|c|}
\hline$(r \xi) r \cdot r$ & هيئت علمى \\
\hline$(\Delta F) Y F I$ & غير هيئت علمى \\
\hline ( & امام رضا \\
\hline$(r \Delta) \backslash \| r$ & قائم \\
\hline$(r, r \Delta) \mid$. & علوى \\
\hline سו & كامياب \\
\hline
\end{tabular}

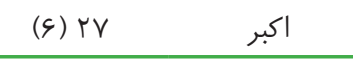

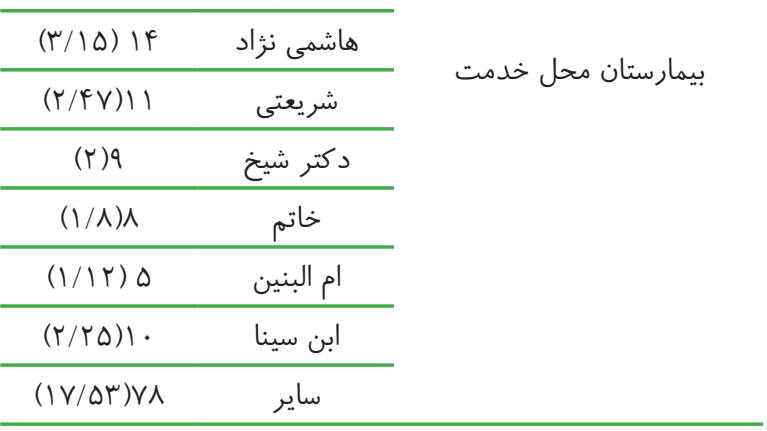

بر اساس يافتههاى جدول شماره بَ، بز شكان با تخصص عمومى با

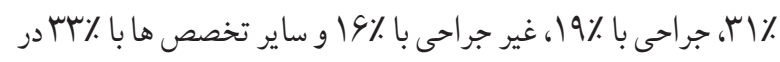

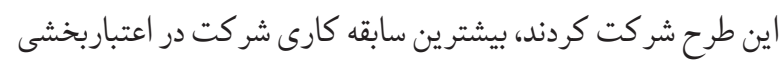
و فعاليتهاى بهبود كيفيت در رده بين ا تا • ا سال سابقه كارى بود،

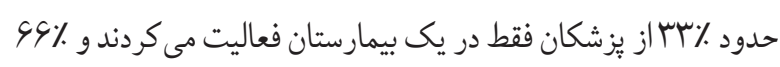

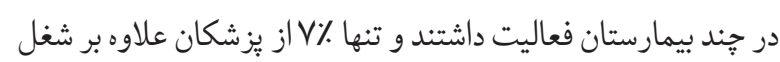
يزشكى در حرفه دي ديخرى مشغول به كار بودند (جدول Y ).
• 1. تو انمند سازى يزشكان در زمينه اعتباربخشى و بهبود كيفيت:

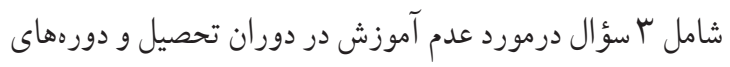

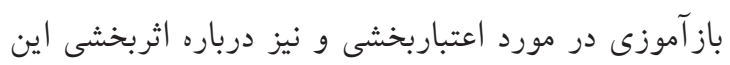
آزمون ها تآنو 1 ا. ارتباط اثربخش (ا سؤال) درباره نقش ارتباط يزشكان با

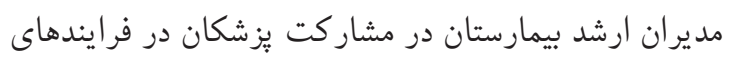
اعتباربخشى T ا. محدوديت منابع (ا سؤال) در مورد نقش وجود محدوديت منابع مالى بر مشاركت يزشكان در فرايندهاى اعتباربخشى سؤ الات اختصاصى يرسشنامه در رابطه با جالشهاى مشاركت يزشكان در برنامههاى اعتباربخشى بر اساس مقياس ه گزينهاى ليكرت (بسيار موافقم، مو افقم، نظرى ندارم، مخالفم و بسيار مخالفم)

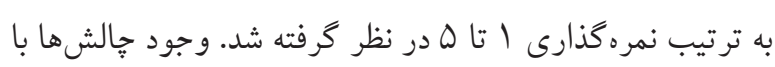

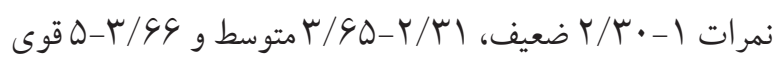

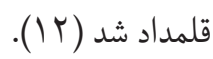
براى تحليل داده ها، آمار توصيفى مشتمل بر فراوانى، درصد، ميانكين و انحراف معيار و آمار استنباطى شامل آزمون كاى دو، از نرم افزار STATA نسخه 1 أستفاده شد. در اين مطالعه به منظور رعايت مسائل اخلاقى سعى شد يس از جلب رضايت و موافقت افراد از آنها درخواست شود نسبت به تكميل يرسشنامه ها اقدام نما يند، در ضمن كليه تضمينهاى الزم به منظور اطمينان از محرمانه ماندن اطلاعات يرسشنامه انجام گرفت (براى تكميل يرسشنامه نيازى به ذكر نام نبود). اين يُوهش با رعايت ملاحضات اخلاقى در كميته سازمانى اخلاق در دانشعاه علوم پيزشكى مشهد با كد IR.MUMS.REC.1398.263 مورد بررسى و تصويب قرار گرفت.

بافته ها

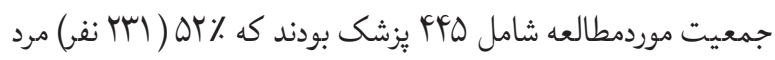

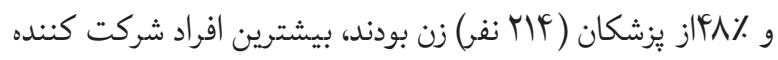

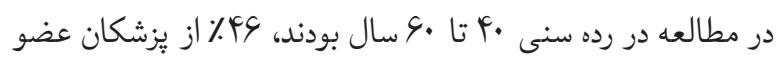




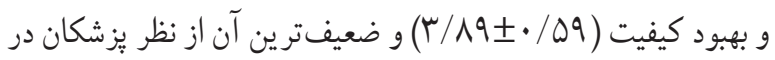

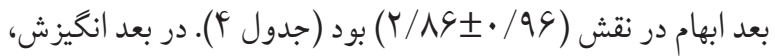

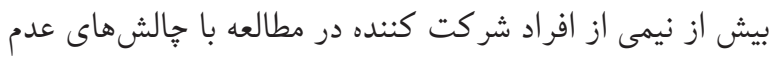

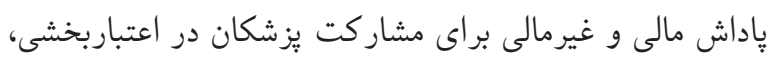

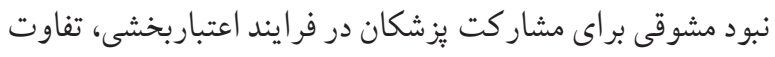

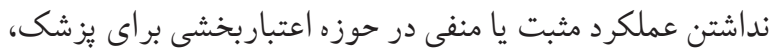

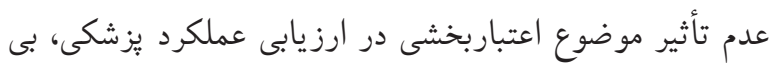

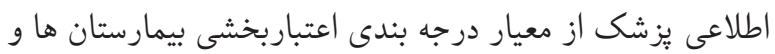

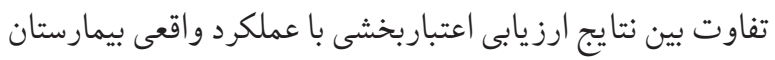

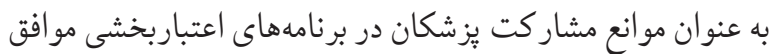

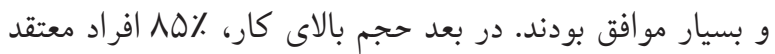

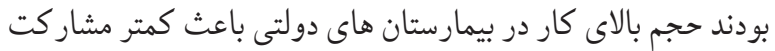

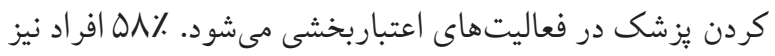

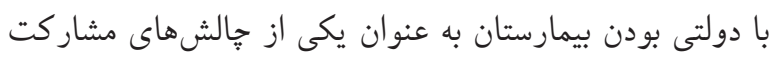
يزشكان در برنامهاى اعتباربخشى موافق و بسيار موافق بودند.

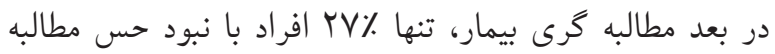

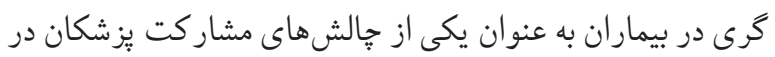

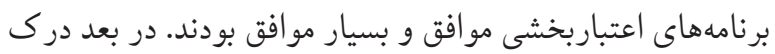

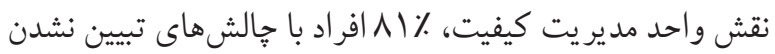

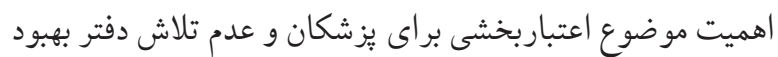

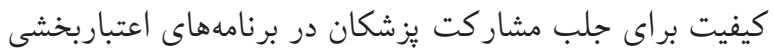

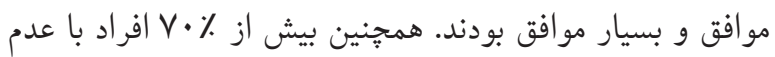

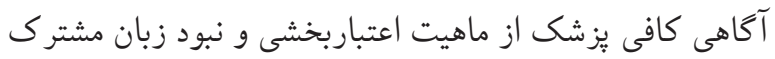

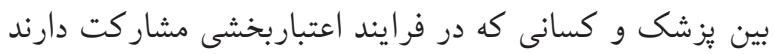
به عنوان جالشهاى مشار كت يز شكان در برنامهاى اعتباربخشى

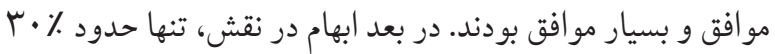

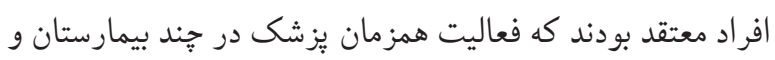
جند شغله بودن يز شك باعث عدم مشاركت يز شكان در برنامههاى اعتباربخشى مىشود. در بعد عدم اطمينان به نحوه مشار كت، حدود \% 9 افر اد نهادينه

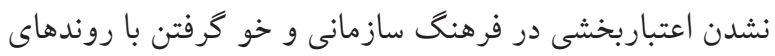

جدول r: فراوانى يزشكان از نظر سطح تخصص، سابقه كارى در

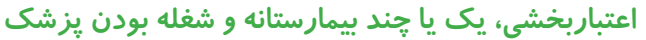

\begin{tabular}{|c|c|c|}
\hline تعداد (درصد) & 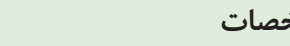 & \\
\hline$(\mathbb{m} \mid / \mathcal{F} s) \mid \mathcal{F}$. & عمومى & \multirow{4}{*}{ سطح تخصص } \\
\hline$(19 / 1 \cdot) \wedge \Delta$ & جراحى & \\
\hline$\left(\mid s / g^{W}\right) V^{\mathbb{F}}$ & غير جراحى & \\
\hline ع & ساير تخصص ها & \\
\hline$(F F) \backslash 9 G$ & بدون سابقه كارى & \multirow{3}{*}{ فابقه كارى در } \\
\hline$(r \varepsilon) r \cdot \Delta$ & بين 1 تا · إ سال سابقه & \\
\hline$(1 \cdot) F F$ & بالاى · كارى سال سابقه & \\
\hline$(r r / V \backslash) \backslash 0$. & فقط در يك بيمارستان & \multirow{2}{*}{ يك يا بيش إز يز شك در } \\
\hline$(\varsigma q / r q)) q \Delta$ & در جند بيمارستان فعاليت & \\
\hline$(q \mu) F \mid r$ & فقط يزشك هست & \\
\hline سח(V) & 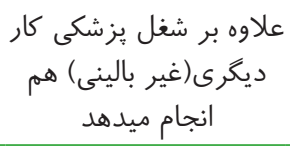 & يك يا خند شغله بودن \\
\hline
\end{tabular}

در جدول ץ نتايج آزمون كاى دو در متغيرهاى كيفى مطالعه

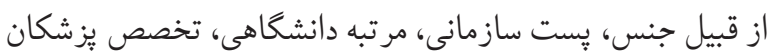

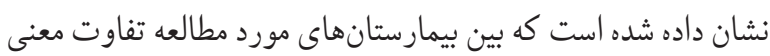
دارى در تخصص، پِت سازمانى و جنس وجود دارد (ه • / > p). جدولَّ: نتيجه آزمون كاى دو در متغيرهاى كيفى مطالعه

\begin{tabular}{|c|c|c|c|}
\hline تخصص & يست سازمانى & جنس & مشخصات \\
\hline \multirow[t]{3}{*}{$\mathrm{P}=\cdot / \ldots$ 粠 } & $\begin{array}{c}\chi r=r r / q \Lambda \\
P=\cdot / \ldots \text { 米* }\end{array}$ & $\begin{array}{l}\chi r=r \cdot / 0 . \\
P=\cdot / \cdot r q *\end{array}$ & بيمار ستان \\
\hline & $\begin{array}{c}\chi r=r / \Delta r \\
P=\cdot / r \mid\end{array}$ & $\begin{array}{c}\chi r=1 / \cdots \\
P=\cdot / \wedge\end{array}$ & تخصص \\
\hline & & $\begin{array}{c}\chi r=r / \cdot \\
P=\cdot / \cdot \wedge\end{array}$ & يست سازمانى \\
\hline
\end{tabular}

ميانكين جالشهاى موجود براى مشاركت يُشكان در اعتباربخشى

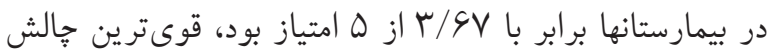

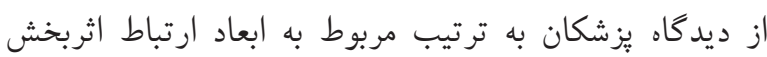

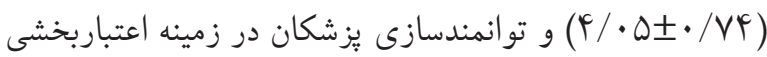


جدول عا: توزيع فراوانى و درصد سؤالات حوزههاى مختلف از ديدكًاه يزشكان

\begin{tabular}{|c|c|c|c|c|c|c|c|c|c|c|c|c|}
\hline \multirow{2}{*}{ 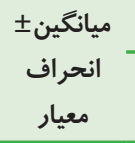 } & \multicolumn{2}{|c|}{ بسيار مخالفم } & \multicolumn{2}{|c|}{ مخالفم } & \multicolumn{2}{|c|}{ نظرى ندارم } & \multicolumn{2}{|c|}{ موافقم } & \multicolumn{2}{|c|}{ بسيار موافقم } & \multirow{2}{*}{ سؤالات } & \multirow{2}{*}{ ابعاد } \\
\hline & درصد & فراوانى & درصد & فراوانى & درصد & فراوانى & درصد & فراوانى & درصد & فراوانى & & \\
\hline$r / \cdot \pm r / \wedge V$ & $1 / 1$ & $\Delta$ & $r / \mu$ & 10 & r & $\Delta \wedge$ & rN/ & IVT & $f r / q$ & 190 & 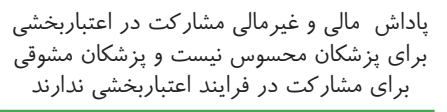 & \multirow{6}{*}{ انخيزش } \\
\hline$r / \pm \Delta \quad 1 / r$ & $r / V$ & rl & $r I / \Lambda$ & $9 \vee$ & $\mid f / \Lambda$ & 94 & 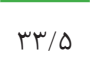 & 149 & $r \Delta / r$ & $11 r$ & 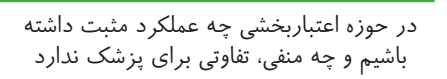 & \\
\hline$r / \cdot \pm s / 9 r$ & $\cdot 10$ & r & $11 / 9$ & $\Delta \mu$ & $r s / 0$ & 111 & $F r / l$ & 194 & 11 & $\wedge$. & در ارزيابى عملكرد بزشكى، موضوع اعتباربخشى نمى & \\
\hline$r / l \pm \Lambda / \cdots$ & $\cdot / \mathrm{V}$ & r & $10 / 1$ & SV & $\mid r / F$ & $\Delta \Delta$ & $f s / f$ & $r \cdot v$ & $r \Delta / \mathcal{A}$ & r & هزشك معيار درجه بندى اعتباربخشى بيمارستان & \\
\hline \multirow[t]{2}{*}{ r/.土人/qr } & .10 & r & $9 / r$ & $q_{1}$ & $r \cdot / r$ & 9 . & $f \mid / \Lambda$ & ING & rN/r & Irs & نتايج ارزيابى اعتبار تبشىى با عملكرد واقعى & \\
\hline & \multicolumn{8}{|c|}{$r / \Lambda \pm \cdot / \& \mu$} & & & ميانكين كل & \\
\hline$\varphi / \cdot \pm 1 / \wedge \varsigma$ & $\cdot 19$ & r & $0 / 9$ & rs & N/1 & rs & $F V / r$ & rl. & $r V / q$ & 199 & 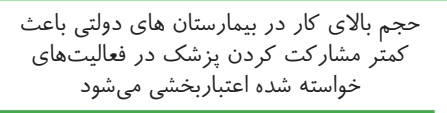 & \\
\hline \multirow[t]{2}{*}{$\mu / \cdot \pm \Delta / \wedge \varphi$} & \multirow[t]{2}{*}{$1 / 1$} & \multirow[t]{2}{*}{$\wedge$} & \multirow[t]{2}{*}{$\mid r / \Lambda$} & \multirow[t]{2}{*}{$\Delta V$} & \multirow[t]{2}{*}{$r s / V$} & 119 & $r r / \Delta$ & \multirow[t]{2}{*}{119} & \multirow[t]{2}{*}{$19 / r$} & Vr & 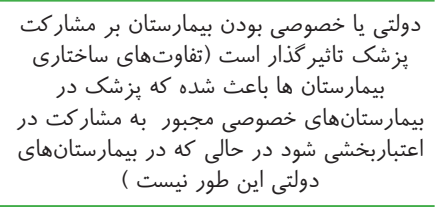 & 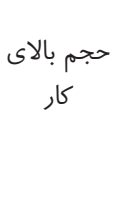 \\
\hline & & & & & & $\mu / \Lambda \pm$ & $=\cdot / V Y$ & & & & ميانگين كل & \\
\hline$r / I \pm N / r$ & $9 / 4$ & pr & rו/l & Ir⿲ & $\mu r / l$ & Ifr & $r T / V$ & 1.1 & $r / V$ & rl & نبود حسار مطت در اعتباربخشى در بيماران بر رفنتى دارد درى & \\
\hline 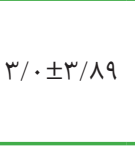 & $1 / 4$ & $\checkmark$ & IV & VA & $\mu r / \Lambda$ & 100 & $r q / 4$ & IVS & $\checkmark$ & ו & 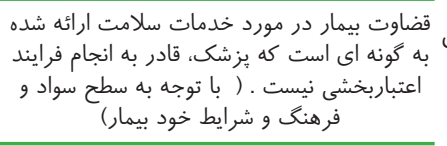 & مطالبه گرم \\
\hline & & & & $r / \cdot V$ & $\pm \cdot / V F$ & & & & & & ميانكين كل & \\
\hline$r / I \pm V / \cdot r$ & $1 / 9$ & $\checkmark$ & $\mid V / r$ & $\checkmark V$ & $1 \cdot / 9$ & iv & $\Delta \cdot / \mu$ & TrF & $r \cdot / r$ & 9 . & 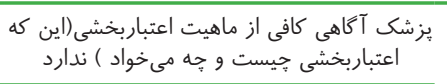 & \\
\hline$r / \cdot \pm q / \wedge q$ & $1 / \mu$ & 4 & $1 \cdot / 1$ & $\varphi \Delta$ & $\checkmark$ & r & $\Delta 9 / 4$ & r\&Q & rr & 91 & اهميت موضوع اعتبارهنشى براى يزشكان تبيين & درى \\
\hline$r / \cdot \pm q / \vee q$ & . & . & $4 / 9$ & ו & $11 / r$ & 0. & $\Delta \Lambda$ & $r \Delta \Lambda$ & $r \mu / \Lambda$ & 1.9 & دفتر بهبود كيفيت براى جلب مشار كت يزشكام دهان & مقش واحد \\
\hline$r / \cdot \pm \Lambda / \wedge r$ & $\cdot / 0$ & r & $9 / 0$ & rq & IN/A & $\Delta F$ & $\Delta r$ & Grs & rI/l & $9 F$ & 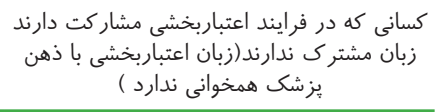 & كيفيت \\
\hline & & & & 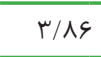 & $\pm \cdot 199$ & & & & & & ميانگين كل & \\
\hline$r / 1 \pm q / \cdot r$ & $s / r$ & rᄉ & qr/q & 101 & $r s / 0$ & 111 & $r V / F$ & IrT & $\Delta / \Lambda$ & rs & 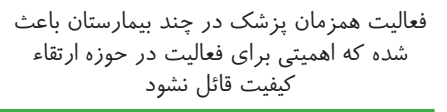 & \\
\hline$r / I \pm \Lambda / \cdot V$ & $9 / T^{f}$ & Fr & $r \Delta / \Delta$ & 101 & rs & 119 & $r \mu / r$ & $1 \cdot{ }^{k}$ & $\Delta / \varsigma$ & ro & 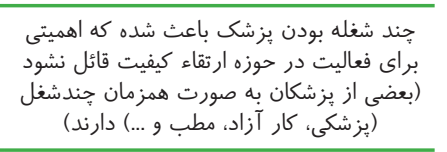 & نقش \\
\hline & & & & r/AS & $\pm \cdot / 99$ & & & & & & ميانگين كل & \\
\hline
\end{tabular}


ادامه جدول عا: توزيع فراوانى و درصد سؤالات حوزههاى مختلف از ديدكاه يزشكان

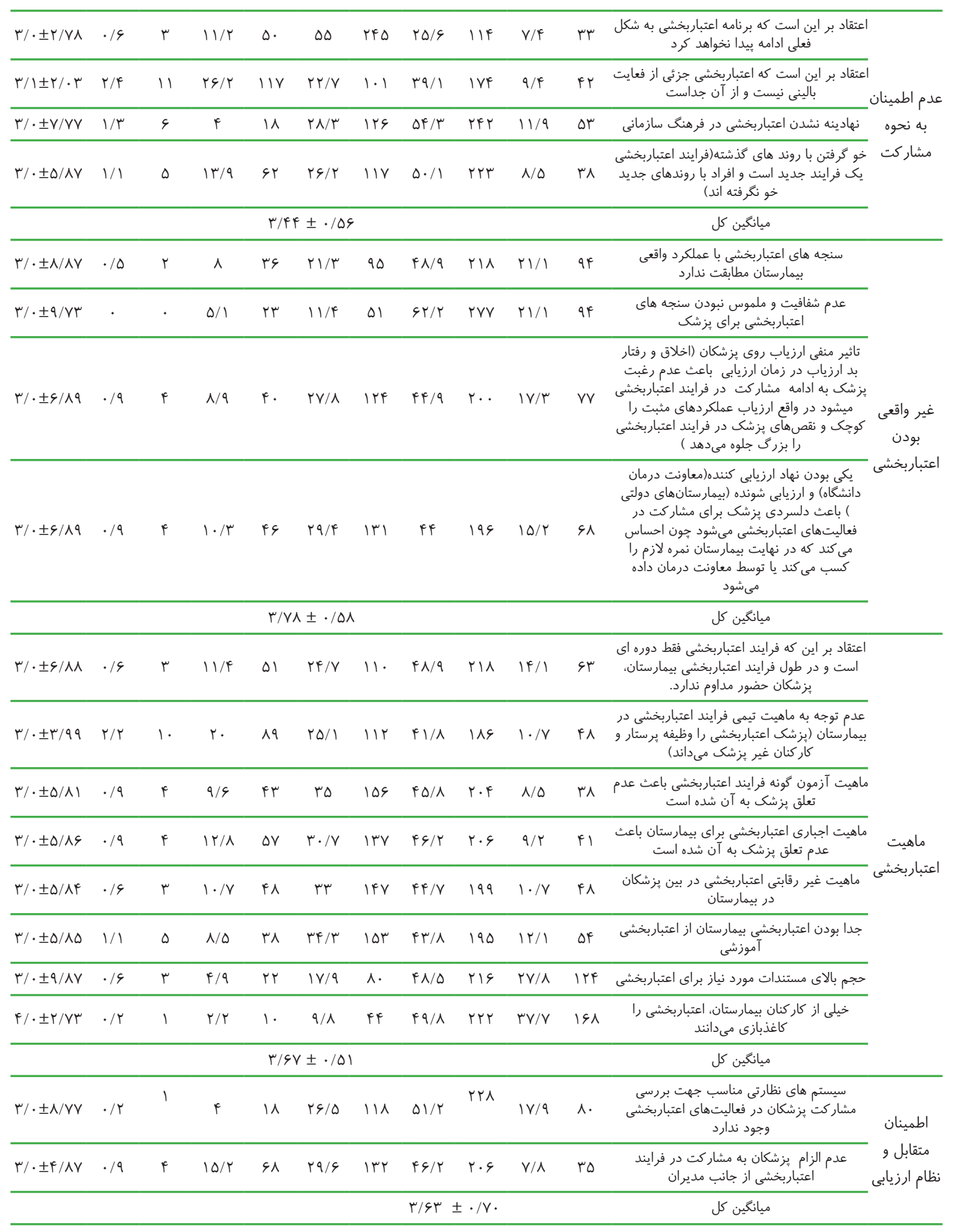


ادامه جدول عا: توزيع فر اوانى و درصد سؤالات حوزههاى مختلف از ديدگًاه يزشكان

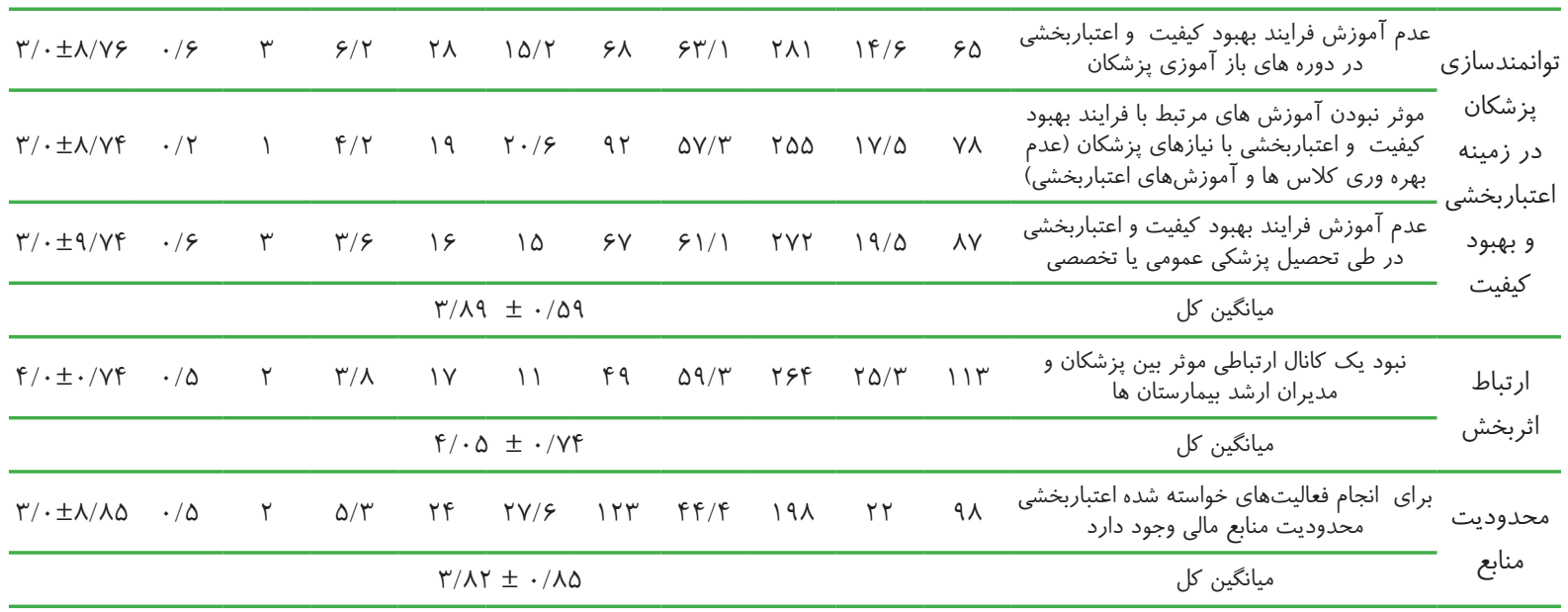

و اعتباربخشى در در طى تحصيل يزشكى عمومى يا تخصصى و نيز در دوره هاى باز آموزى يزشكان به عنوان جالشهاى مشار كت يزشكان در برنامههاى اعتباربخشى موافق و بسيار موافق بودند. در بعد ارتباط اثربخش، AF\% افراد با جالش نبود يك كانال ارتباطى موثر بين يزشكان و مديران ارشد بيمارستان ها موافق و بسيار موافق بودند. در بعد محدوديت منابع، 94\% افر اد با محدوديت منابع مالى براى انجام فعاليتهاى خواسته شده اعتباربخشى به عنوان جالش مشار كت يزشكان در اين برنامه ها موافق و بسيار موافق بودند. با توجه به جدول ه، در جالشهاى مشاركت قسمت مطالبه گرى بيمار بين حداقل دو گروه از ميانكين ها در تخصصهاى مختلف تفاوت معنى دارى وجود دارد (ه • / • p).

بحث و نتيجه كيرى هدف اين يثوهش تبيين جالشهاى مشاركت يزشكان در برنامههاى اعتباربخشى در بيمارستانهاى دولتى شهر مشهد در سال 99 11 بود. اجراى اعتباربخشى مستلزم تغييرات بسيار زيادى در رفتار، فرهنگ و ساختارسازمانى بيمارستان است تا منجر بهبود عملكرد يزشكان در انجام فعاليتهاى اعتباربخشى بيمارستانى شود (II) ). در اين مطالعه جالش هاى يِيش روى مشاركت يزشكان در برنامههاى اعتباربخشى در با بعد انكيزش، حجم بالاى كار، مطالبه گرى بيمار، درك نقش واحد مديريت كيفيت، ابهام در نقش، عدم اطمينان به
كذشته را در عدم مشاركت يزشكان در برنامههاى اعتباربخشى مؤثر دانستند. در بعد غير واقعى بودن اعتباربخشى، \% 1 افر اد با جالش عدم شفافيت و ملموس نبودن سنجه هاى اعتباربخشى براى يزشك، \% 1 أفراد با جالش تاثير منفى ارزياب روى يزشكان و ه9\% افراد با جالش يكى بودن نهاد ارزيابى كننده موافق و بسيار موافق بودند. در بعد ماهيت اعتباربخشى، 19\% يزشكان شر كت كننده در مطالعه اعتباربخشى را كاغذبازى مىدانستند. VY\% افر اد با جالش حجم بالاى مستندات مورد نياز براى اعتباربخشى موافق و بسيار مو افق بودند. همجنين بيش از نيمى از افراد شر كت كننده در مطالعه با دوره اى بودن فرايند اعتباربخشى و عدم حضور مداوم يزشكان در برنامههاى اعتباربخشى، عدم توجه به ماهيت تيمى فرايند اعتباربخشى در بيمارستان، ماهيت اجبارى اعتباربخشى، ماهيت غيررقابتى اعتباربخشى در بين يزشكان در بيمارستان و جدا بودن

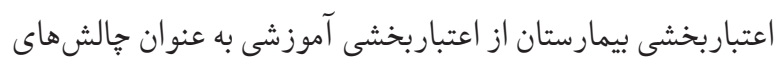
مشاركت يزشكان در برنامههاى اعتباربخشى موافق و بسيار موافق بودند. در بعد اطمينان متقابل و نظام ارزيابى، 99\%افراد با جالش نبود سيستم هاى نظارتى مناسب جهت بررسى مشار كت يزشكان در فعاليتهاى اعتباربخشى و DF\% افر اد با خالش عدم الزام يزشكان به مشاركت در فر ايند اعتباربخشى از جانب مديران موافق و بسيار موافق بودند. در بعد توانمندسازى يزشكان در زمينه اعتباربخشى و بهبود كيفيت، بيش از ٪ V. افر اد با عدم آموزش فرايند بهبود كيفيت 
جدول ه: ارتباط بين گالشهاى مشاركت يزشكان در اعتباربخشى با نوع تخصص يزشكان

\begin{tabular}{|c|c|c|c|c|c|}
\hline \multirow{2}{*}{ نتيجه آزمون } & ساير تخصص ها & غير جراحى & 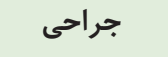 & 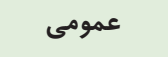 & \\
\hline & \multicolumn{4}{|c|}{ ميانكين土 انحراف معيار } & \\
\hline $\mathrm{F}=\cdot / 1 \wedge, \mathrm{p}=\cdot / 9 \mid$ & $\cdot|\varsigma| \pm r / \Lambda$. & $\cdot / \varsigma \wedge \pm r / \wedge \mu$ & $\cdot / s \mu \pm r / V \wedge$ & $\cdot|q| \pm r / \wedge f$ & 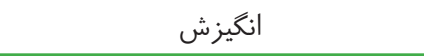 \\
\hline$F=r / r \cdot p=\cdot / \cdot V$ & $\cdot / V F \pm r / q$ & $\cdot / \varsigma q \pm p / \ldots$ & $\cdot / V \mathcal{F} \pm Y / V I$ & $\cdot / \varsigma \vee \pm r / \wedge \varsigma$ & حجم بالاى كار \\
\hline $\mathrm{F}=r / 9 r, \mathrm{p}=\cdot / \cdot r$ & $\cdot / V A \pm r / I r$ & $\cdot / V Y \pm r / Y \Delta$ & $\cdot / V V \pm r / 9 r$ & $\cdot / r \cdot \pm r / r$ & مطالبه گرى بيمار \\
\hline$F=r / l r, p=\cdot / \cdot q$ & $\cdot / g F \pm r / \Lambda r$ & $\cdot|q| \pm f / \cdot q$ & $\cdot|c| \pm r / \wedge \Delta$ & $\cdot / V I \pm r / \wedge r$ & درك نقش واحد مديريت كيفيت \\
\hline $\mathrm{F}=l / l r, \mathrm{p}=\cdot / \mu r$ & $\cdot / 9 \wedge \pm r / V V$ & $\cdot / 9 \varsigma \pm r / \wedge \varsigma$ & $\cdot / \wedge \Lambda \pm \mu / \cdot \mid$ & $\cdot / 9 \vee \pm r / \wedge \varsigma$ & ابهام در نقش \\
\hline $\mathrm{F}=1 / \wedge \cdot, \mathrm{p}=\cdot / 1 \mathrm{f}$ & $\cdot|\Delta s \pm r / F|$ & $\cdot / \Delta r \pm r / \Delta V$ & $\cdot / 01 \pm \mu / \mu \wedge$ & $\cdot / \Delta \Lambda \pm r / \mathbb{F}$ & عدم اطمينان به نحوه مشار كت \\
\hline $\mathrm{F}=1 / \wedge \cdot, \mathrm{p}=\cdot / 1 \mathrm{f}$ & $\cdot|s| \pm r / V \Delta$ & $\cdot / \Delta r \pm r / 9 r$ & $\cdot / \Delta F \pm r / V \Delta$ & $\cdot / 4 \cdot \pm r / v \Delta$ & غيرواقعى بودن اعتباربخشى \\
\hline $\mathrm{F}=1 / 44, \mathrm{p}=\cdot / 1 \mathrm{~V}$ & $\cdot / 0 \cdot \pm \mu / q \mu$ & $\cdot / \Delta \Delta \pm r / V \wedge$ & $\cdot / 0 \cdot \pm r / s V$ & $\cdot / \Delta \cdot \pm r / s \mu$ & ماهيت اعتباربخشى \\
\hline $\mathrm{F}=1 / \Delta r, \mathrm{p}=\cdot / r$ & $\cdot / V \Delta \pm r / \Delta F$ & $\cdot / \varsigma \vee \pm r / V$ & $\cdot / \varsigma \vee \pm Y / V r$ & 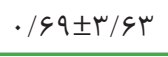 & اطمينان متقابل و نظام ارزيابى \\
\hline $\mathrm{F}=\cdot / 4 \cdot, \mathrm{p}=\cdot|4|$ & $\cdot / \Delta V \pm r / \wedge q$ & $\cdot / q \mathcal{F} \pm r / 9 \vee$ & $\cdot / 0 \cdot \pm r / \wedge \varsigma$ & $\cdot / \varsigma \cdot \pm r / \wedge \varsigma$ & توانمند سازى يزشكان در حوزه كيفيت \\
\hline $\mathrm{F}=r / r \wedge, \mathrm{p}=\cdot / \cdot \vee$ & $\cdot / V Y \pm r / \cdot \varphi$ & $\cdot / r^{\mu} \pm F / r q$ & $\cdot / V \mid \pm F / \cdot 1$ & $\cdot / V V \pm r / 9 V$ & 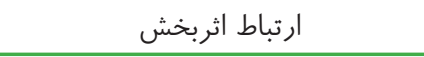 \\
\hline $\mathrm{F}=1 / r q, \mathrm{p}=\cdot / r V$ & $\cdot / \Lambda I \pm r / \wedge F$ & $\cdot / \Lambda 1 \pm r / 9 V$ & $\cdot / \vee q \pm r / V q$ & $\cdot / 9 \cdot \pm r / V \Delta$ & محدوديت منابع \\
\hline
\end{tabular}

اعتباربخشى نداشته باشند. ييشنهاد مىشود با الكو گيرى مناسب از كشورهاى موفق در حوزه اعتباربخشى بيمارستانى در سراسر دنيا

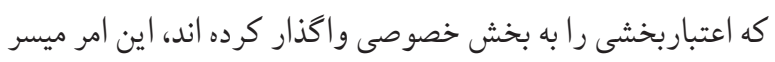

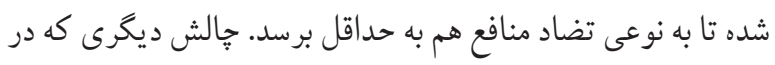

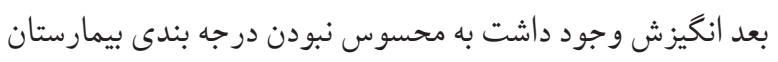

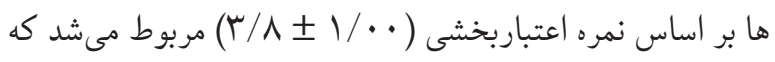

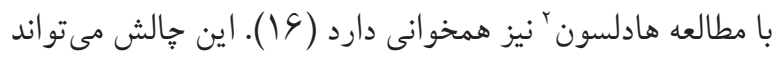

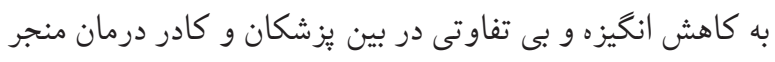

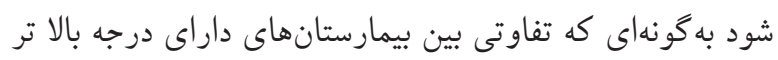

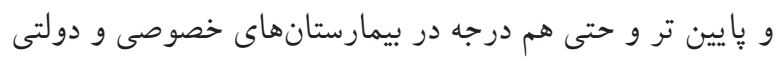

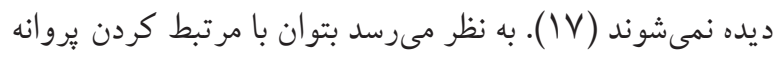

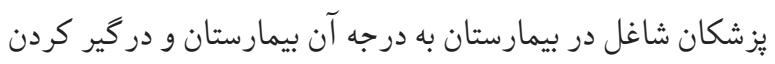

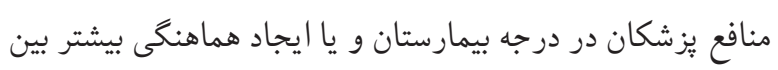

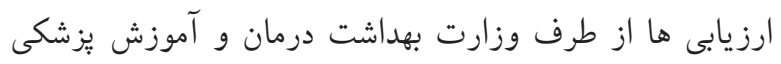

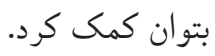

در بعد مطالبه كرى بيمار، تصور نادرست از قضاوت بيمار

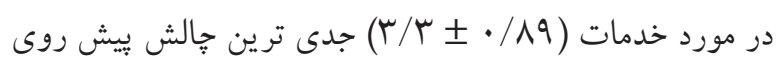
2. Hudelson
نحوه مشاركت، غير واقعى بودن اعتباريخشى، ماهيت اعتباربخشى،

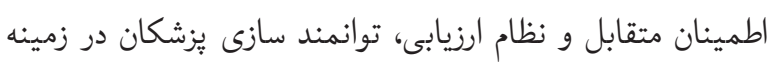

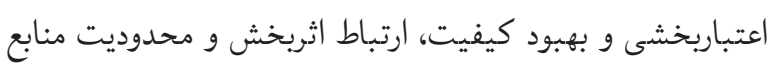
مورد بررسى قرار كرفت.

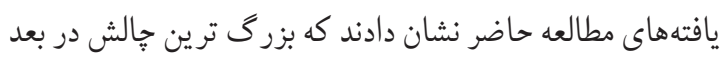

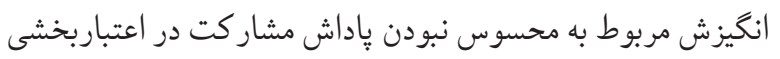

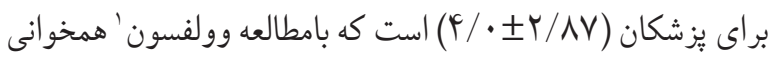

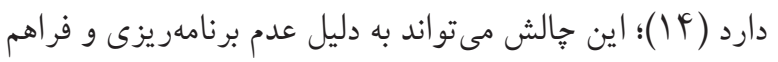

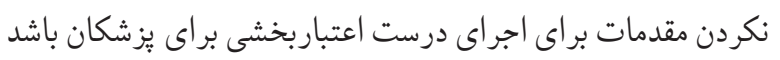

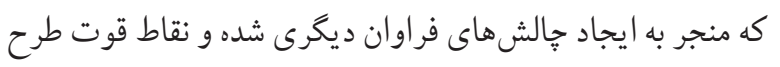

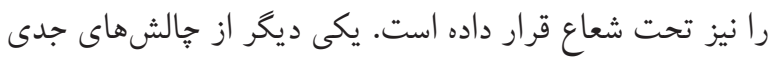

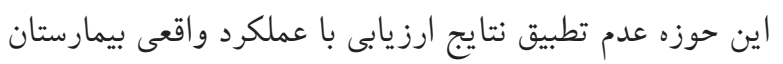

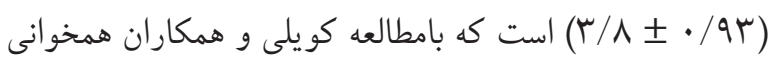
دارد (1) (1). استفاده نكردن از بخش خصوصى در ارزيابى هائ برنامه اعتباربخشى و امتيازدهى بر اساس نظر ات شخصى باعث مى شيود

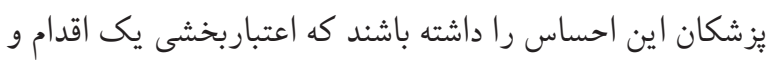

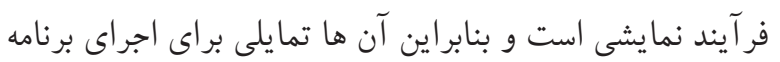
1. Wolfson 
فعاليتهاى انجام شده در بيمارستان از سوى يزشك و گنجانده

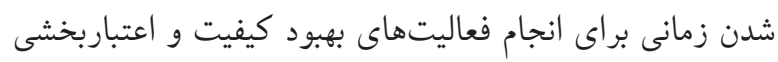

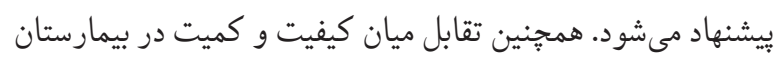

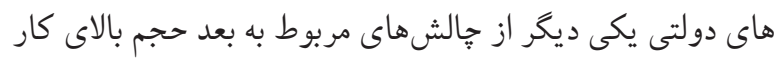

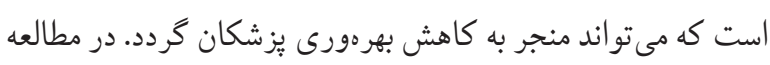

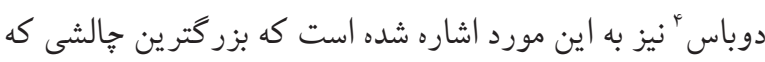
فرايندهاى اعتباربخشى و بهبود كيفيت دارد يِيدا كردن نقطه تعادل

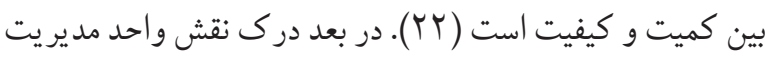
كيفيت، جالش عمده مربوط به عدم درى اهميت اعتباربخشى از

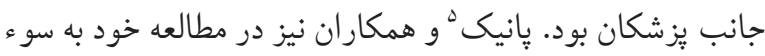

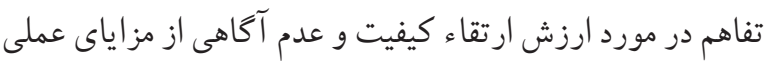

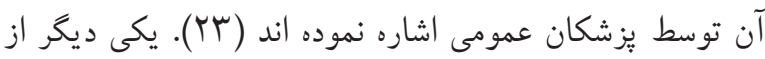

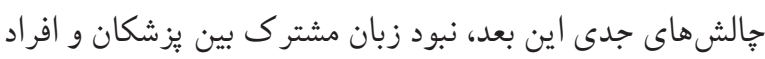

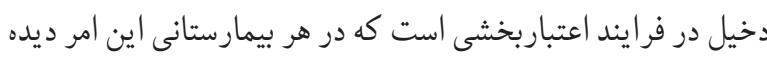

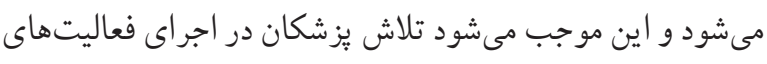

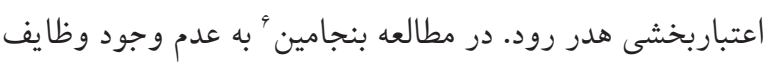

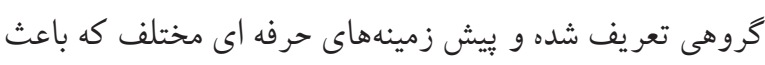

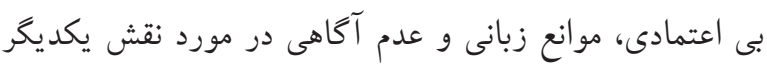

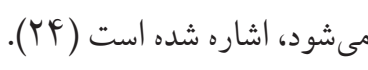

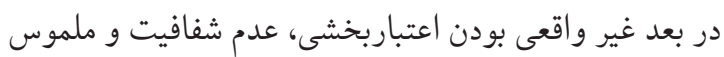

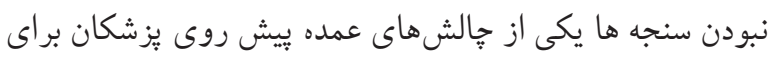

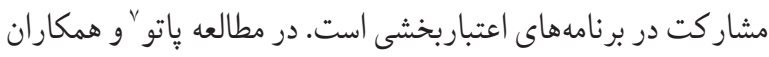
بيان شد كه عدم شفافيت در مورد جمع آورى دادههاى محرمانه بيمار و الزامات استفاده از دادههاى بالينى در تحقيقات، به ويثه انتشار

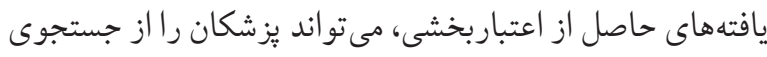

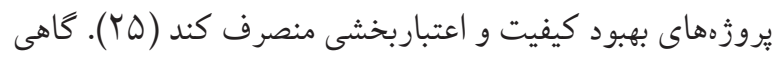

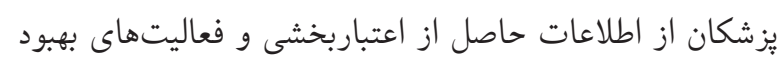

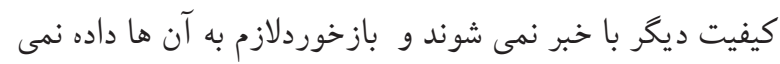

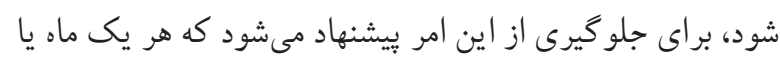

4. Dubas

5. Pannick

6. Benjamin

7. Patow

يزشكان براى مشاركت در برنامه اعتباربخشى بود. مارشال ' نيز

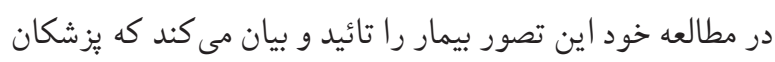

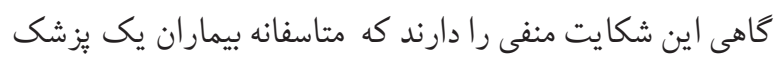

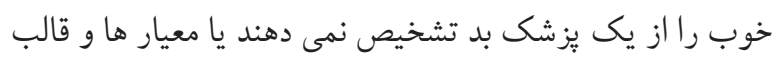
ذهنى بيماران در مورد كيفيت كار يزشك متفاوت هست (V)

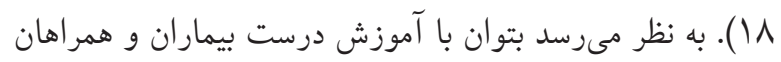
آن ها به رفع اين جالش كمك كرد. اهميت بعد مطالبه گرى بيمار در مشار كت بز شكان در برنامهاى اعتباربخشى در ساير مطالعات

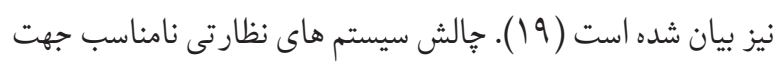

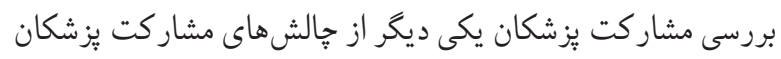
در برنامههاى اعتباربخشى مى باشد كه در بعد اطمينان متقابل و نظام

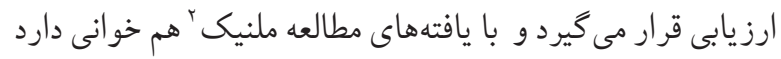

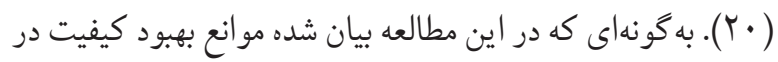

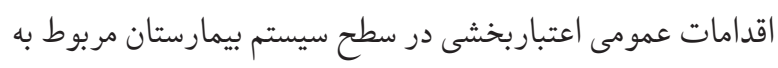
عدم يا ناكافى بودن حمايت دولت يا مقامات بهداشتى است. فقدان

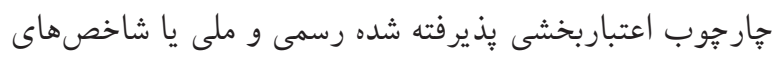

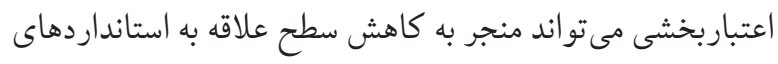

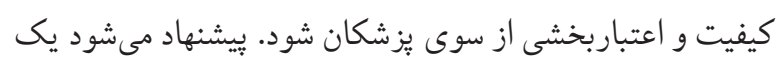

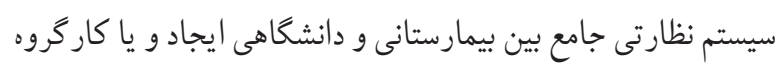

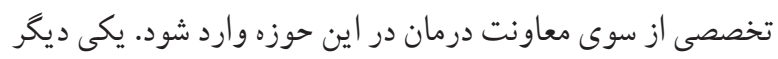

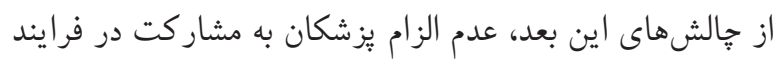

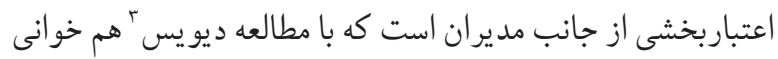

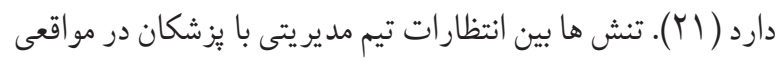

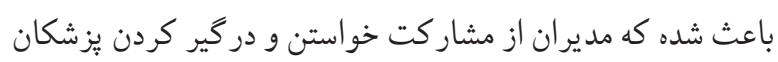
در فرايندهاى اعتباربخشى امتناع كنند. يكى ديكر از ابعاد مورد بررسى مربوط به بعد حجم بالاى كار بود. حجم بالاى كار در بيمارستان هاى دولتى به كم كارى و عدم انجام

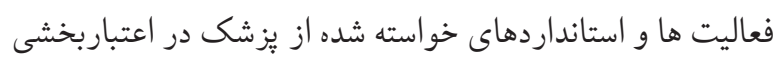
منجر مىشود. بهمنظور رفع اين مشكل، بازنخرى در دسته بندى 
و مديران نيز از موانع سازمانى براى مشاركت بز شكان در اجراى

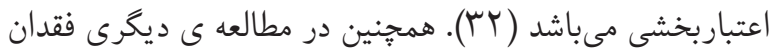

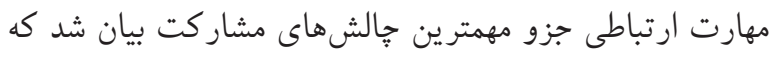

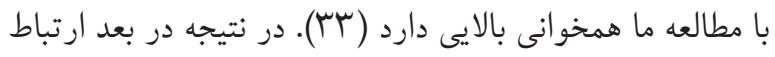

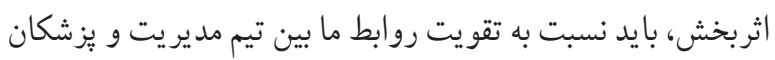

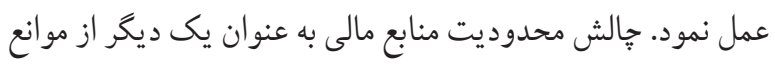
مشاركت در مطالعه حاضر ياد شده است. در مطالعهى ديكرى نيز به اين موضوع اشاره شده است كه نبود منابع مالى كافى به عنوان

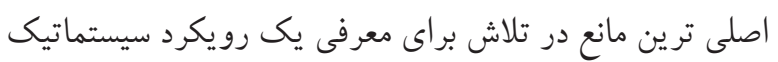

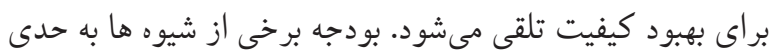

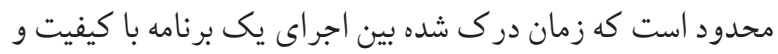

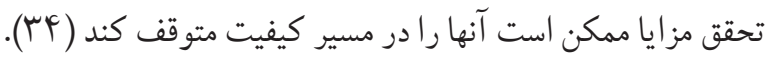

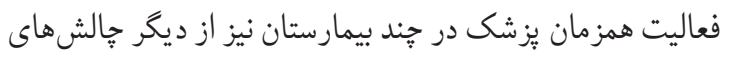
يبش روى يزشكان براى مشاركت در اعتباربخشى است. يافتهاى

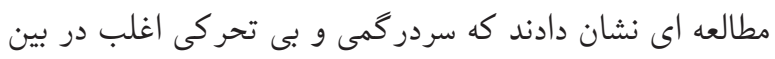
يزشكانى كه در هند بيمارستان فعاليت دارند در مورد اينكه جها

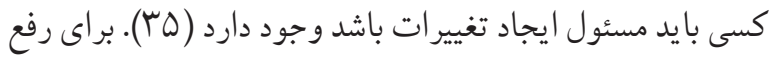

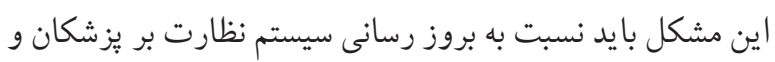

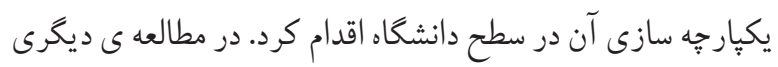

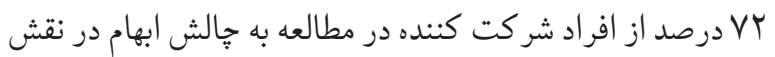

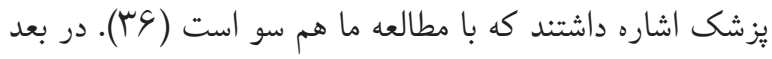

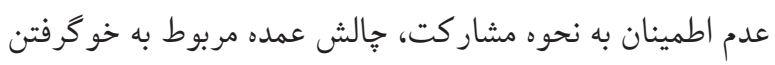
با روندهاى كذشته است. جونز 'و همكاران اظهار داشتند كه تغيير

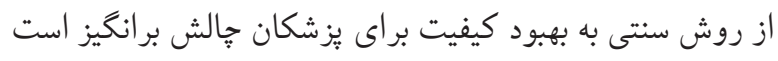
(TV)

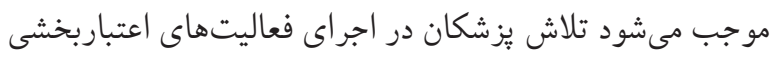

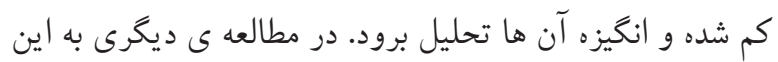

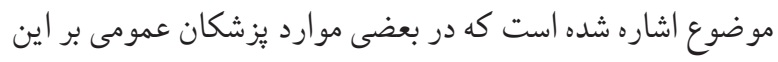

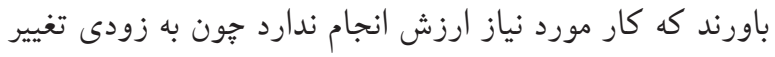

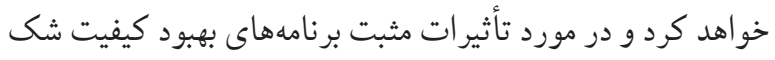

حداقل هر ب ماه نتايج حاصل از اعتباربخشى به صورت ايميل يا

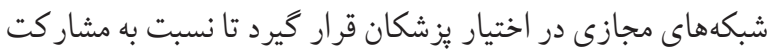
رغبت بيشترى بيدا كند. جالش ديكر اين بعد، عدم تطبيق سنجه هاى اعتباربخشى با عملكرد واقعى بيمارستان است. در مطالعه

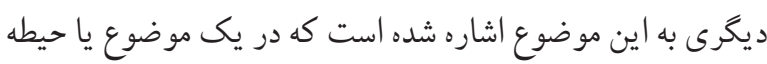

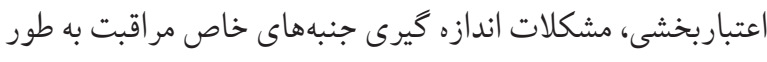

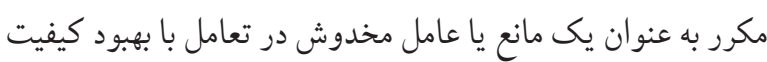

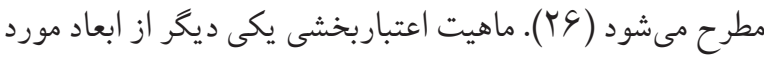

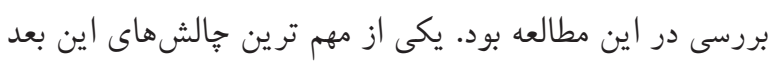

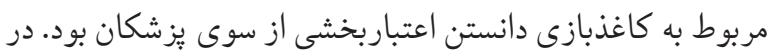

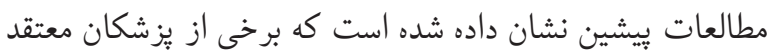

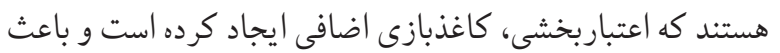

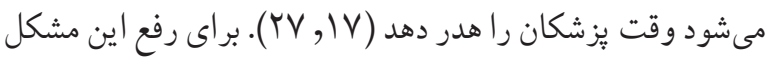

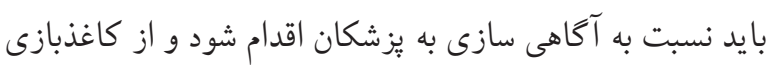

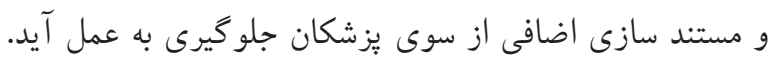

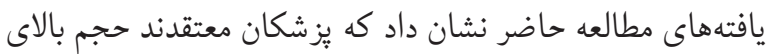
مستند سازى در اعتباربخشى منجر به اتلاف و هدررفتن بز شكان إنان

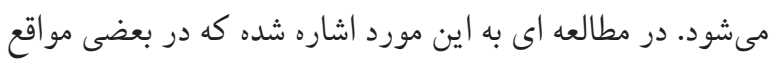

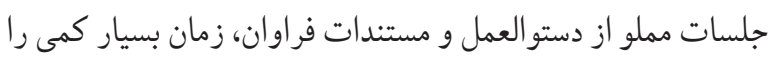
براى انجام يروزههاى اعتبار بخشى رامى كذارد كه منجر به مو انعى إنى

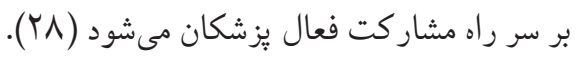
عدم آموزش فرايند بهبود كيفيت و اعتباربخشى در طى تحصيل

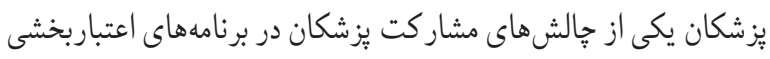

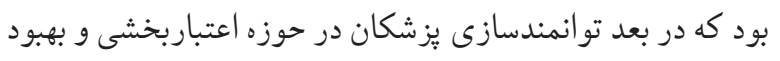

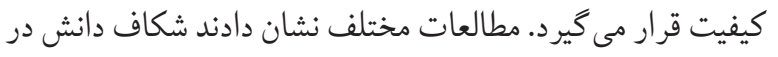
دوران تحصيل در ارتباط با آموزشهاى اعتباربخشى ممكن است باعث شود كه بِّكان كمتر از شايستكى دانشكاهى و وبتانسيل

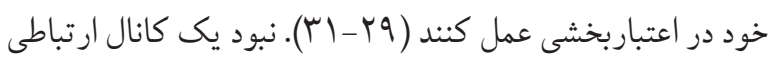

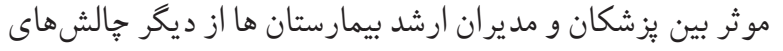

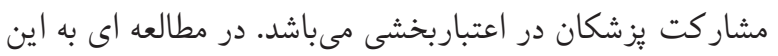

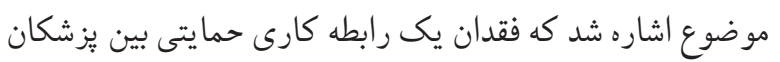




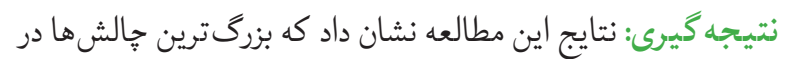
ابعاد ارتباط اثربخش، توانمند سازى يزشكان در زمينه اعتباربخشى إيى و بهبود كيفيت و بعد انكيزش است كه رفع اين جالشها، كمك شايانى به بهبود عملكرد يزشكان در فعاليتهاى اعتباربخشى خواهد كرد. كمترين جالش نيز مربوط به بعد ابهام در نقش مىشد. با توجه به اينكه تمام جالشهاى شناسايىشده در اين مطالعه حائز اهميت هستند، بيشنهاد مىشود بهمنظور اجراى صحيح فعاليتهاى اعتباربخشى آن گونه كه اهداف اين طرح و تعريف بين المللى و شناختهشده آن در سطح جهان و كشورهايى كه طرح را اجرا كردهاند مطابقت داشته باشد، سياست گذاران عزم جدى در رفع جالشها داشته باشند. تشكر و قدردانى: اين مقاله حاصل بخشى از پايان نامه كارشناسى ارشد با عنوان ) بررسى جالشهاى مشاركت پيزشان در فعاليتهاى اعتباربخشى در بيمارستانهاى دانشگاه علوم يزشكى مشهد ) است

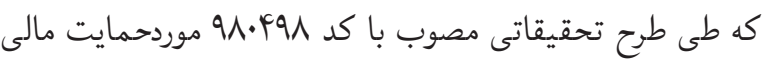
دانشخاه علوم يزشكى مشهد قرارگرفته است. بدينوسيله از همكارى كسانى كه ما را در انجام يزوهش يارى نمودند، قدردانى مينماييم. تضاد منافع: هيج كونه تضاد منافعى كزارش نشده است.

\section{References}

1. Charoghchian Khorasani E, Tavakoly Sany SB, Tehrani H, Doosti H, Peyman N. Review of Organizational Health Literacy Practice at Health Care Centers: Outcomes, Barriers and Facilitators. International Journal of Environmental Research and Public Health. 2020;17(20):7544. https://doi.org/10.3390/ijerph 17207544 PMid:33081335 PMCid:PMC7589923

2. MeyersD, MillerT,GenevroJ,ZhanC, DeLaMareJ,FournierA, et al. EvidenceNOW: balancing primary care implementation and implementation research. 2018;16(Suppl 1):S5-S11. h tt p s: / / d o i . org / 10.1370 / a f m. 2196 PMid:29632219 PMCid:PMC5891307

3. Gharibi F, Tabrizi JSJHpp. Development of an accreditation model for health education and promotion programs in the Iranian primary healthcare system: a Delphi study. 2018;8(2):155. https://doi.org/10.15171/hpp.2018.20 PMid:29744312 PMCid:PMC5935820

4. Afshari A, Eslami A-a, Mostafavi F, Moazam E, Golzari M,
و ترديد شديد دارند (^)). در نتيجه براى افزايش فرهنگ مشاركت در بين يزشكان بايستى آموزشهاى لازم را از همان دوران تحصيل در مورد اهميت بهبود كيفيت براى بيمار و خود يزشك ارائه نمود و در بيمارستان هم سعى شود از يزشكان باسابقه تر براى فرهنگ سازى و الكو گيرى استفاده شود، همجنين مى توان در شرح وظايف يزشكان مشار كت در بهبود كيفيت و فعاليت هاى اعتباربخشى را قيد كرد و براى آن ضريبى رادر نظر كرفت. يكى از نقاط قوت مطالعه حاضر اين است كه براى اولين بار با استفاده از يرسشنامه جالشهاى مشار كت يزشكان در برنامههاى اعتباربخشى به طور جامع ال بعد مؤثر بر مشاركت يزشكان در برنامههاى اعتباربخشى را مورد بررسى قرار داده است. همجنين انتخاب يزشكان به عنوان متخصصانى كه اصلى ترين نقش را در مدير يت بالينى بيماران برعهده دارند از ديخر نقاط قوت مطالعه حاضر مىباشد. با اين حال، با توجه به اينكه مطالعه حاضر صرفا به بيان ديد گاههاى يزشكان برداخته است ممكن است بسيارى از جالشهاى ييش روى ساير متخصصين حوزه سلامت ناديده گرفته شود. ييشنهاد ميشود مطالعات بعدى مشاركت ساير متخصصين حوزه سلامت در فر ايند اعتباربخشى را نيز مورد بررسى قرار دهند.

Etminani R. Self-assessment for implementation of health promotion standards in hospitals, in medical education centers of Isfahan city. Iranian Journal of Health Education and Health Promotion. 2020;8(3):249-60. https://doi.org/10.29252/ijhehp.8.3.249

5. Singh K, Drouin K, Newmark LP, Rozenblum R, Lee $J$, Landman A, et al. Developing a framework for evaluating the patient engagement, quality, and safety of mobile health applications. 2016;5(1):11. https://doi.org/10.15868/socialsector.25066

6. Mathews SC, Demski R, Hooper JE, Biddison LD, Berry SA, Petty BG, et al. A model for the departmental quality management infrastructure within an academic health system. 2017;92(5):608-13. https://doi.org/10.1097/ACM.0000000000001380 PMid:27603038

7. Willcocks SG, Wibberley GJLiHS. Exploring a shared leadership perspective for NHS doctors. 2015. https://doi.org/10.1108/LHS-08-2014-0060 
PMid:26388222

8. Ferdosi $M$, Ziyari FB, Ollahi MN, Salmani AR, Niknam NJJoE, Promotion H. Implementing clinical governance in Isfahan hospitals: Barriers and solutions, 2014. 2016;5. https://doi.org/10.4103/2277-9531.184554 PMid:27500173 PMCid:PMC4960764

9. Nair M, Baltag V, Bose K, Boschi-Pinto C, Lambrechts T, Mathai MJJoAh. Improving the quality of health care services for adolescents, globally: a standards-driven approach. 2015;57(3):288-98. https://doi.org/10.1016/j.jadohealth.2015.05.011 PMid:26299556 PMCid:PMC4540599

10. Mainz J, Kristensen S, Bartels PJIJfQiHC. Quality improvement and accountability in the Danish health care system. 2015;27(6):523-7. https://doi.org/10.1093/intqhc/mzv080 PMid:26443814

11. Li J, Hinami K, Hansen LO, Maynard G, Budnitz T, Williams MV. The physician mentored implementation model: a promising quality improvement framework for health care change. Academic Medicine. 2015;90(3):303-10. https://doi.org/10.1097/ACM.0000000000000547 PMid:25354069

12. Ebrahimipour $H$, Houshmand $E$, Varmaghani $M$, Mojtabaeian SM. Psychometrics of Assessment Tools to Examine the Challenges of Physicians' Participation in Accreditation Programs. Management Strategies in Health System. 2021:54-63. https://doi.org/10.18502/mshsj.v6i1.6508

13. Baker R, Bała M, Czabanowska K, Dubas K, Eriksson T, Godycki-Ćwirko $\mathrm{M}$, et al. Guidebook on implementation of Quality Improvement in General Practice. 2010.

14. Wolfson D, Bernabeo E, Leas B, Sofaer S, Pawlson G, Pillittere DJBFP. Quality improvement in small office settings: an examination of successful practices. 2009;10(1):14. https://doi.org/10.1186/1471-2296-10-14 PMid:19203386 PMCid:PMC2649044

15. Coyle Y, Mercer S, Murphy-Cullen C, Schneider G, Hynan LJBQ, Safety. Effectiveness of a graduate medical education program for improving medical event reporting attitude and behavior. 2005;14(5):383-8. https://doi.org/10.1136/qshc.2005.013979 PMid:16195575 PMCid:PMC1744080

16. Hudelson P, Cléopas A, Kolly V, Chopard P, Perneger TJBQ, Safety. What is quality and how is it achieved? Practitioners' views versus quality models. 2008;17(1):31-6. https://doi.org/10.1136/qshc.2006.021311 PMid:18245217

17. Ebrahimipour $H$, Hooshmand $E$, Varmaghani M, Javan-Noughabi J, Mojtabaeian SM. The challenges of physicians' participation in hospital accreditation programs: a qualitative study in Iran.
BMC Health Services Research. 2021;21(1):1171 https://doi.org/10.1186/s12913-021-07182-w PMid:34711235 PMCid:PMC8555276

18. Marshall MJTHFII. Are clinicians engaged in quality improvement. 2011.

19. Algunmeeyn A, El-Dahiyat F, Alfayoumi I, Alrawashdeh MJIJoHM. Exploring staff perspectives of the barriers to the implementation of accreditation in Jordanian hospitals: Case study. 2020:1-7. https://doi.org/10.1080/20479700.2020.1763233

20. Melnyk BM, Gallagher-Ford L, Fineout-Overholt E. Implementing the evidence-based practice (EBP) competencies in healthcare: a practical guide for improving quality, safety, and outcomes: Sigma Theta Tau; 2016.

21. Davies H, Powell A, Rushmer RJAlr. Healthcare professionals' views on clinician engagement in quality improvement. 2007;4.

22. Dubas K, Kijowska VJGoioQliGP. Barriers to implement Quality Improvement. 2010:73.

23. Pannick S, Sevdalis $N$, Athanasiou TJBq, safety. Beyond clinical engagement: a pragmatic model for quality improvement interventions, aligning clinical and managerial priorities. 2016;25(9):716-25. https://doi.org/10.1136/bmjqs-2015-004453 PMid:26647411 PMCid:PMC5013121

24. Benjamin AJB. Audit: how to do it in practice. 2008;336(7655):1241-5 https://doi.org/10.1136/bmj.39527.628322.AD PMid:18511799 PMCid:PMC2405828

25. Patow CA, Karpovich K, Riesenberg LA, Jaeger J, Rosenfeld JC, Wittenbreer $M$, et al. Residents' engagement in quality improvement: a systematic review of the literature. 2009;84(12):1757-64. https://doi.org/10.1097/ACM.0b013e3181bf53ab PMid:19940586

26. Boonyasai RT, Windish DM, ChakrabortiC, Feldman LS, Rubin HR, BassEBJJ.Effectiveness ofteaching qualityimprovement to clinicians: a systematic review. 2007;298(9):1023-37. https://doi.org/10.1001/jama.298.9.1023 PMid:17785647

27. Boyle A, Keep JJBJoHM. Clinical audit does not work, is quality improvement any better? 2018;79(9):508-10. https://doi.org/10.12968/hmed.2018.79.9.508 PMid:30188196

28. Nair P, Barai I, Prasad S, Gadhvi KJAiME, Practice. Quality improvement teaching at medical school: a student perspective. 2016;7:171. https://doi.org/10.2147/AMEP.S101395 PMid:27051330 PMCid:PMC4807889

29. Hooper P, Kocman D, Carr S, Tarrant CJPMJ. Junior doctors' views on reporting concerns about patient 
safety: a qualitative study. 2015;91(1075):251-6. https://doi.org/10.1136/postgradmedj-2014-133045 PMid:25898840

30. Bethune RMJJotRSoM. The leaders of quality improvement are the ones who are doing the improvement work. 2013;106(6):210https://doi.org/10.1177/0141076813489929 PMid:23761579 PMCid:PMC3705418

31. Bagnall PJTKSFJDPLTKF. Facilitators and barriers to leadership and quality improvement. 2012.

32. Foy R, Skrypak M, Alderson S, Ivers NM, Mclnerney B, Stoddart J, et al. Revitalising audit and feedback to improve patient care. 2020;368. h tt p s : / / d o i . or g / 10.1136 / b m j.m 213 PMid:32107249 PMCid:PMC7190377

33. Stephen SO, Bula HJHRM. Human resource management practices and quality of health care service delivery at Jaramogi Oginga Odinga teaching and referral hospital, Kenya. 2017:126-40.

34. Woodall P, Borek A, Parlikad AKJI, management. Data quality assessment: the hybrid approach. 2013;50(7):369-82. https://doi.org/10.1016/j.im.2013.05.009

35. Biancone P, Tradori V, Brescia V, Migliavacca A. Quality and control in the healthcare: a win-win mix? 2017.

36. Shah GH, Leep CJ, Ye J, Sellers K, Liss-Levinson R, Williams KSJJoPHM, et al. Public health agencies' level of engagement in and perceived barriers to PHAB national voluntary accreditation. 2015;21(2):107-15. https://doi.org/10.1097/PHH.0000000000000117 PMid:25010327

37. Jones B, Vaux E, Olsson-Brown AJB. How to get started in quality improvement. 2019;364. htt ps://doi .org / 10.1136 / b m j.k5437 PMid:30655245 PMCid:PMC6335598

38. Ewins E, Macpherson R, van der Linden G, Arnott SJBB. Training in quality improvement for the next generation of psychiatrists. 2017;41(1):45-50. https://doi.org/10.1192/pb.bp.115.051409 PMid:28184318 PMCid:PMC5288094 